\begin{tabular}{|c|c|}
\hline $\begin{array}{l}\text { 2. To: (Receiving organization) } \\
\text { SST Engineering }\end{array}$ & $\begin{array}{l}\text { 3. From: (Originating Organization) } \\
\text { SST Engineering }\end{array}$ \\
\hline 5. Proj./Prog./Dept./Div.: & $\begin{array}{l}\text { 6. Design Authority/ Design Agent/Cog } \\
\text { Engr.: }\end{array}$ \\
\hline TWRS/Tech Ops \& & $\begin{array}{l}\text { RW Reed/ARES Corporation/D } \\
\text { Reberger }\end{array}$ \\
\hline
\end{tabular}

8. Originator Remarks:

This engineering study performed by ARES Corporation in response to Solicitation 12750-GA is being released through LMSI Document Control in order to ensure future retrievability.

11. Receiver Remarks: 11A. Design Baseline Document? [] Yes [X] No
4. Related EDI NO.:

$N / A$

7. Purchase Order No.:

\section{7-Release 3}

9. Equip./Component No.:

$\mathrm{N} / \mathrm{A}$

10. System/Bldg./Facility:

TWRS/241/Db1-She11 Tanks

12. Major Assm. Dwg. No.:

N/A

13. Permit/Permit Application No.: $N / A$

14. Required Response Date:

$N / A$

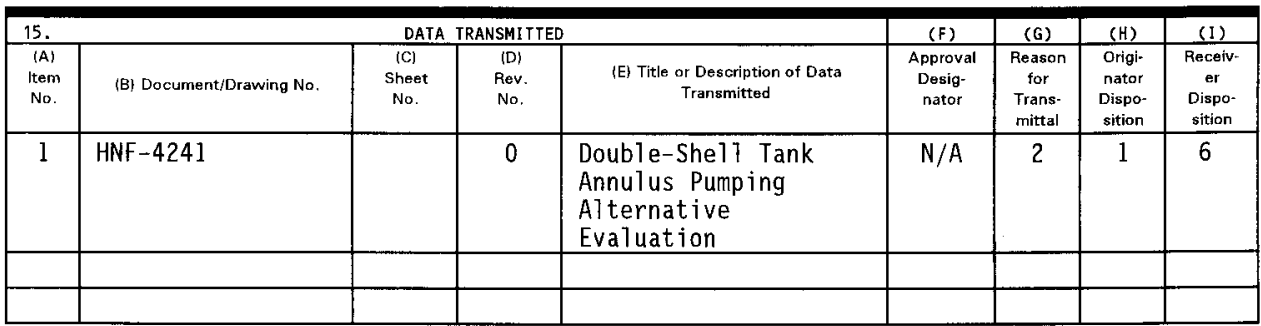

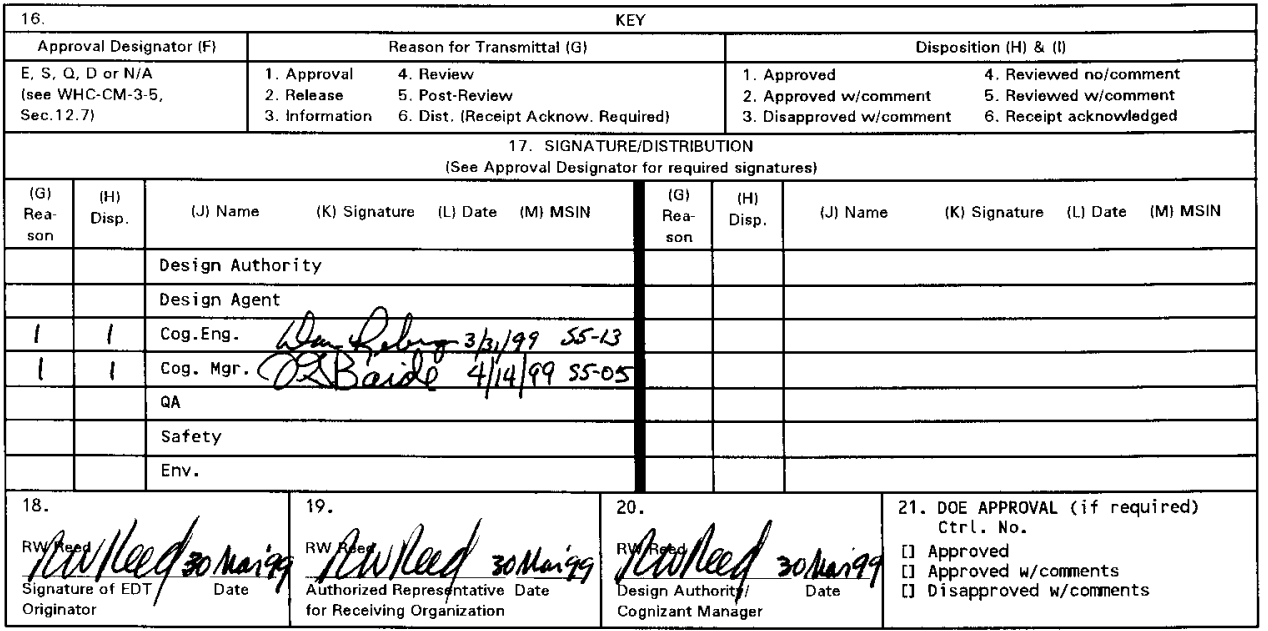


HNF-4241, Rev. 0

\section{DOUBLE-SHELL TANK ANNULUS PUMPING ALTERNATIVE EVALUATION}

SD Riesenweber

T Salzano

Lockheed Martin Hanford Company, Richland, WA 99352

U.S. Department of Energy Contract DE-AC06-96RL13200

EDT/ECN: $616409 \quad$ UC: 2020

Org Code: $74800 \quad$ Charge Code: 106673 BC20

B\&R Code: EW3130010 Total Pages: 40

Key Words: Double-Shell Tank, Emergency, Pumping, Secondary Containment, Annulus, Alternative, Evaluation

Abstract: This engineering evaluation compares five alternative schemes for maintaining emergency annulus pumping equipment in a reliable condition. The five schemes are: 1) continue status quo; 2)periodic pump removal and run-in;3) periodic in-place limited maintenance; 4) uninstalled ready spares; and 5) expanded mission of Single-Shell Tank Emergency Pumping Trailer. Each alternative is described, the pros and cons identified, and rough order of magnitude life-cycle costs computed. The alternatives are compared using weighted evaluation criteria. The evaluation concludes that staging adjustable length submersible pumps in the Single-Shell Tank Emergency Pumping Trailer has the best cost-benefit characteristics.

TRAIMARE [IGCLIMEF. Reterence hereit to any specific commercial product, proceas, or

servise by trade rame, trademark, manufacturer, or otherwiae, does not necessarily

institut a imply its endorsement, recomendaton, or favortrig by the united states

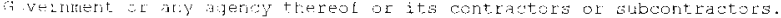

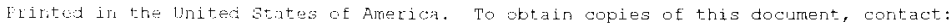

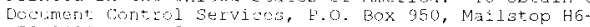

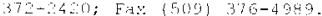
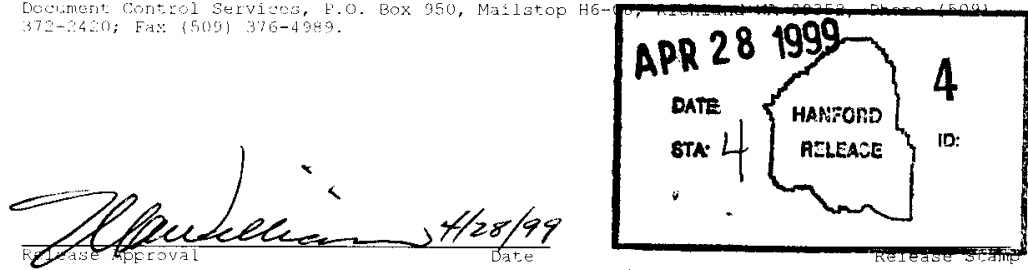

Approved for Public Release 


\title{
DOUBLE-SHELL TANK ANNULUS PUMPING ALTERNATIVE EVALUATION
}

\author{
Prepared for
}

\section{LOCKHEED MARTIN HANFORD COMPANY \\ Contract No. 677 - Release 003 \\ Report No. 9905303-001 \\ Revision 0}

March 1999

Prepared by

\section{ARES CORPORATION}

636 Jadwin Avenue, Suite B

Richland, Washington 99352 


\title{
DOUBLE-SHELL TANK ANNULUS PUMPING ALTERNATIVE EVALUATION
}

\author{
Prepared for \\ LOCKHEED MARTIN HANFORD COMPANY \\ Contract No. 677 - Release 003 \\ Report No. 9905303-001 \\ Revision 0
}

March 1999

Prepared by: Stephen D. Riesenweber Tom Salzano, P.E.

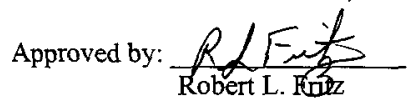
Date: $3-5-99$ 


\section{TABLE OF CONTENTS}

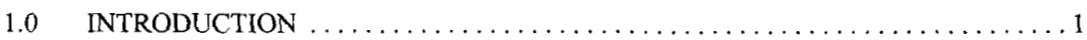

2.0 EVALUATION METHODOLOGY $\ldots \ldots \ldots \ldots \ldots \ldots \ldots \ldots \ldots \ldots \ldots \ldots$

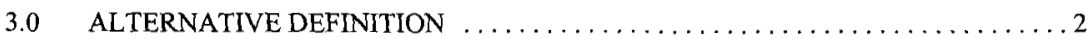

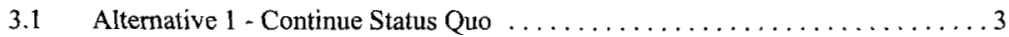

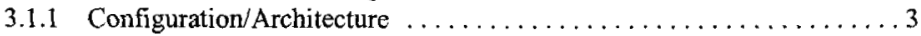

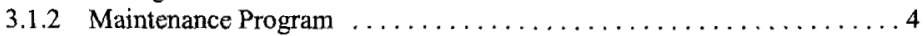

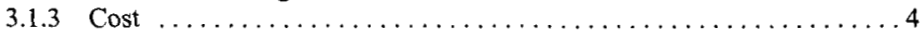

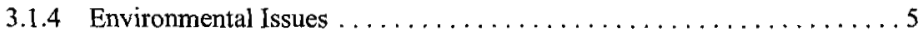

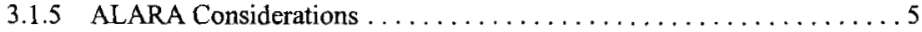

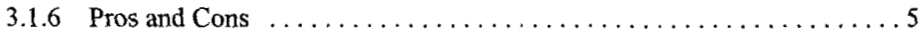

3.2 Alternative 2 - Periodic Pump Removal and Run-In . . . . . . . . . . . 6

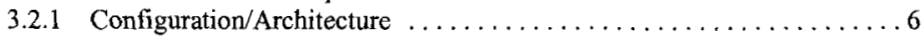

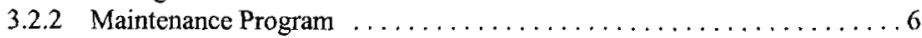

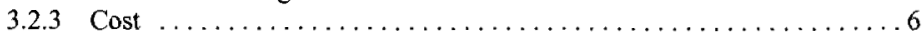

3.2 .4 Environmental Issues $\ldots \ldots \ldots \ldots \ldots \ldots \ldots \ldots \ldots \ldots \ldots \ldots \ldots$

3.2 .5 ALARA Considerations $\ldots \ldots \ldots \ldots \ldots \ldots \ldots \ldots \ldots \ldots \ldots$

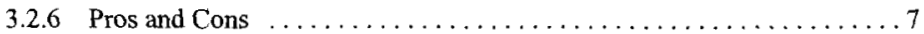

3.3 Alternative 3 - Periodic In-Place Limited Maintenance $\ldots \ldots \ldots \ldots \ldots \ldots 7$

3.3.1 Configuration/Architecture $\ldots \ldots \ldots \ldots \ldots \ldots \ldots \ldots \ldots$

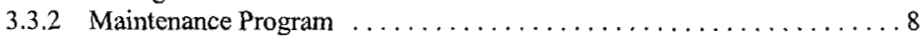

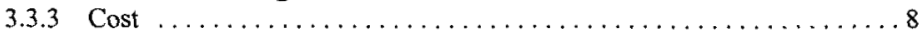

3.3.4 Environmental Issues $\ldots \ldots \ldots \ldots \ldots \ldots \ldots \ldots \ldots \ldots \ldots \ldots \ldots$

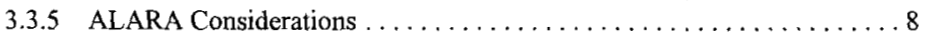

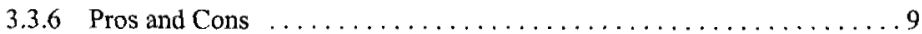

3.4 Alternative 4 - Uninstalled Ready Spares $\ldots \ldots \ldots \ldots \ldots \ldots \ldots \ldots \ldots$

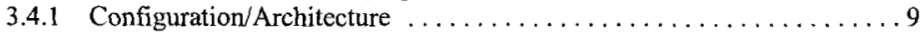

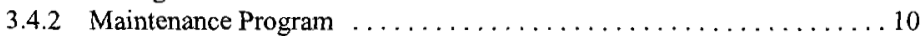

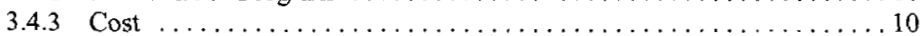

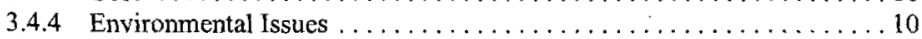

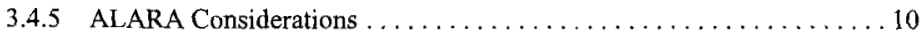

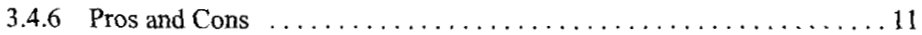

3.5 Alternative 5 - Expanded Mission of SST Emergency Pumping Trailer . . . . . . 11

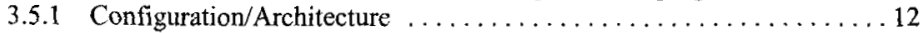

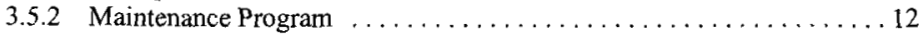

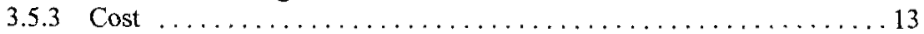

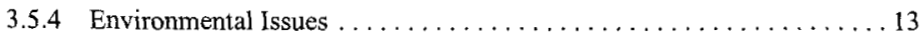


Double-Shell Tank Annulus Pumping Alternative

EVALUATION

Report No. 9905303-001, Rev. 0 March 1999

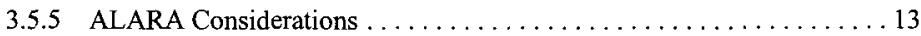

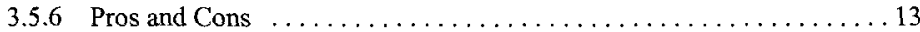

4.0 ALTERNATIVE EVALUATION $\ldots \ldots \ldots \ldots \ldots \ldots \ldots \ldots \ldots \ldots \ldots \ldots \ldots \ldots$

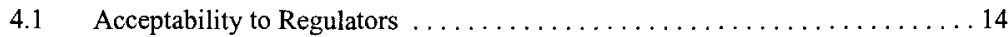

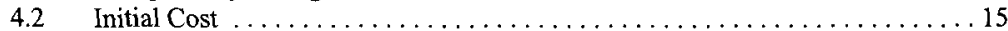

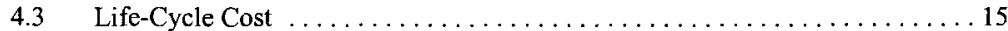

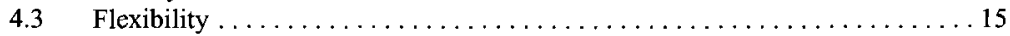

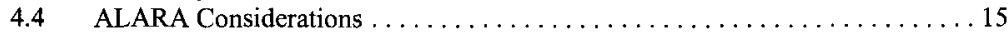

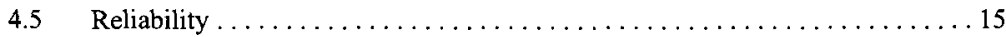

5.0 SUMMARY/RECOMMENDATIONS $\ldots \ldots \ldots \ldots \ldots \ldots \ldots \ldots \ldots \ldots$

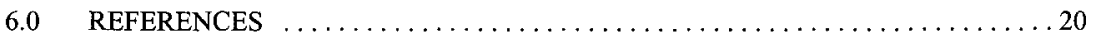

\section{APPENDICES}

Appendix A

Double-Shell Tank Annulus Pumping Data $\ldots \ldots \ldots \ldots \ldots \ldots \ldots \ldots$ A-1

Appendix B

Estimated Initial, Maintenance, and D\&D Costs for Alternatives . . . . . . . . . B-1 Appendix C

Alternative Life-Cycle Cost Information 


\section{TABLES}

Table 1. Alternative Evaluation Criteria Weighting Factors $\ldots \ldots \ldots \ldots \ldots \ldots \ldots \ldots \ldots$

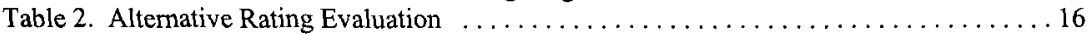

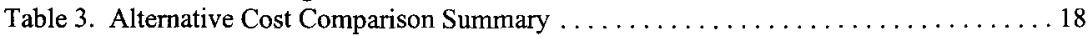

Table 4. Summary of Alternative Comparison Results $\ldots \ldots \ldots \ldots \ldots \ldots \ldots \ldots \ldots$ 


\section{ACRONYMS}
ALARA
As Low As Reasonably Achievable
D\&D
DST
Decontamination and Decommissioning
LMHC
Double-Shell Tank
SST
Lockheed Martin Hanford Corporation
Single-Shell Tank 


\subsection{INTRODUCTION}

Lockheed Martin Hanford Corporation (LMHC) prepared and issued a Double-Shell Tank Emergency Pumping Guide in October 1998 (LMHC 1998). The Washington State Department of Ecology responded to the guide with several questions warranting further evaluation of the emergency pumping plans. One area of concern was centered on the planned approach to double-shell tank (DST) annulus pumping in case of a primary tank leak. In particular, questions were asked regarding the number of existing pumps and spares, the age and maintained condition (operability) of the existing annulus pumps, and the time needed to move an annulus pump from its storage location to the annulus pit of the leaking tank. In response to these questions, this DST Annulus Pumping Alternative Evaluation has been generated. Its intended purpose is to evaluate five approaches to maintaining reliable and effective annulus pumping systems for the DSTs, thereby providing a justification and explanation of the adequacy of the existing approach or a recommended approach(es) to optimizing the cost effectiveness and reliability of the system.

The five alternatives evaluated in the following sections include:
1) Continue Status Quo
2) Periodic Pump Removal and Run-In
3) Periodic In-Place Limited Maintenance
4) Uninstalled Ready Spares
5) Expanded Mission of Single-Shell Tank (SST) Emergency Pumping Trailer.

\subsection{EVALUATION METHODOLOGY}

Initially, all five alternatives were researched to determine the system configuration/architecture, necessary modifications, and annual maintenance programs. Initial and life-cycle costs issues associated with each system, and radiation exposure considerations (ALARA) were also determined for all alternatives.

After defining the alternatives, a team of key individuals knowledgeable of the DST systems, maintenance practices, facility configuration, and programmatic and environmental considerations was assembled. The purpose of this group was to validate the proposed evaluation criteria for each alternative, to establish a basis for ranking the merits of each alternative, and to rank the alternatives. Table 1 contains the agreed upon criteria and the resulting weighting factors. Each criterion was pair-wise compared starting with the highest ranked criteria and moving to the lowest ranked criteria. In the pair-wise comparison only two criteria are compared at once to decide their relative importance (e.g., how much more important is one criteria over the other). Reliability and the acceptability to regulators received the two highest weighting criteria. Reliability is associated with preventive maintenance procedures and 
the impact of failures on the process. The acceptability to regulators is influenced by the completeness of the pumping, the time to pump, and the risk to the environment.

The team then scored the alternatives, with a number between 0 and 100 , with respect to how well each alternative satisfied the identified criteria. The scores were multiplied by the weighting factors for each criterion on each alternative, and the total scores for the five alternatives summed.

Table 1. Alternative Evaluation Criteria Weighting Factors

\begin{tabular}{|l|c|c|}
\hline \multicolumn{1}{|c|}{ Criteria } & \multicolumn{1}{|c|}{$\begin{array}{c}\text { Pair-Wise } \\
\text { Comparison Results }\end{array}$} & $\begin{array}{c}\text { Normalized } \\
\text { Weighting } \\
\text { Factor }\end{array}$ \\
\hline \hline $\begin{array}{l}\text { Acceptability to Regulators } \\
- \text { completeness of pumping } \\
\text { - time to pump } \\
\text { - risk to environment }\end{array}$ & 45 & .26 \\
\hline Initial Cost & 10 & .06 \\
\hline Life-Cycle Cost & 30 &. $\mathbf{1 7}$ \\
\hline Flexibility & 25 & $\mathbf{. 1 4}$ \\
\hline ALARA & 15 & $\mathbf{. 0 9}$ \\
\hline Reliability & 50 & $\mathbf{2 8}$ \\
\hline \hline TOTAL & 175 & $\mathbf{1 0 0}$ \\
\hline
\end{tabular}

\subsection{ALTERNATIVE DEFINITION}

In this section, each of the five alternatives is described with respect to the existing or needed configuration/architecture, proposed maintenance programs, the initial and life-cycle costs, any environmental issues, and ALARA considerations. Appendix A discusses annulus systems common to all DSTs. Appendices B and C provide cost information for each alternative.

The following sections address the configuration of each farm, the maintenance program, the cost, environmental issues, and ALARA considerations of each alternative. The configuration at each farm was determined from previous documents that assessed current DST pumping equipment and dimensional data (LMHC 1998 and WHC 1992). Figure A-1 in Appendix A shows the dimensional data for each annulus pump configuration. 


\subsection{Alternative 1 - Continue Status Quo}

The current annulus pumping scheme for the DST farms is to provide one vertical turbine pump installed in a designated tank's annulus pit (one per Farm). Currently, pumps are installed in the AN-, AP-, AY-, AZ-, and SY-Farms. The annulus pump will need to be moved if the primary tank of a different DST is determined to have a leak. For the AW-Farm, no pump is currently installed. A spare pump located at the 273-EA laydown yard will need to be modified and tested before installation in the AW-Farm.

\subsubsection{Configuration/Architecture}

The AN-Farm consists of seven DSTs that have been in operation since 1981. One vertical turbine annulus pump is available for emergency pumping in the AN-Farm. This pump is currently installed in the 241-AN-07B Annulus Pump Pit and has not been operated or maintained for more than 15 years. The pump, B5P-10, has a design point of $100 \mathrm{gpm}$ at a head of $150 \mathrm{ft}$. In addition, the pump has a length of 46'-2-1/2" and extends to within 3 -in. of the bottom of the annulus. The remaining six annulus pump pit risers are open and no spare pump is available. The clearance height above the riser flange is approximately 8'-2" in each pit.

The AP-Farm consists of eight DSTs that have been in operation since 1986. One annulus pump is available for emergency pumping in the AP-Farm. This pump is currently installed in the 241AP-03B Annulus Pump Pit and has not been operated for approximately 14 years. The pump, $1 \mathrm{P}-\mathrm{AP}-1$, has a design point of $100 \mathrm{gpm}$ at a head of $150 \mathrm{ft}$. In addition, the pump has a length of $46^{\prime} 2-1 / 2^{\prime \prime}$ and extends to within $2-3 / 16^{\prime \prime}$ of the bottom of the tank. The remaining seven annulus pump pit risers are open and no spare pump is available. The clearance height above the riser flange is approximately $8^{\prime}-9^{\prime \prime}$ in each pit.

The AW-Farm consists of six DSTs that have been in operation since 1980. An annulus pump is not currently installed in any of the AW-Farm DSTs, however, a spare is available which will require modification prior to installation. The clearance height above the riser flange is approximately $8^{\prime}-3^{\prime \prime}$ in each pit.

The AY-Farm consists of two DSTs that have been in operation since 1975. One annulus pump is available for emergency pumping in the AY-Farm. This pump is currently in the 241-AY-01F Annulus Pump Pit and has not been operated or maintained for more than 20 years. The pump, 2B-P10, has a design point of $100 \mathrm{gpm}$ at a head of $80 \mathrm{ft}$. In addition, the pump has a length of 46'-1-9/16" and extends to within 2-15/16" of the bottom of the tank. The 241-AY-02F Annulus Pump Pit is open and no spare pump is available. The clearance height above the riser flange is approximately $8^{\prime}-3^{\prime \prime}$ in each pit. 
The AZ-Farm consists of two DSTs that have been in operation since 1977. One annulus pump is available for emergency pumping in the AZ-Farm. This pump is currently in the 241-AZ-01F Annulus Pump Pit and has not been operated or maintained for more than 20 years. The pump, $108 \mathrm{P}-10$, has a design point of $100 \mathrm{gpm}$ at a head of $80 \mathrm{ft}$. In addition, the pump has a length of 46'-1-9/16" and extends to within 2-3/4" of the bottom of the tank. The 241-AZ-02F Annulus Pump Pit is open and no spare pump is available. The clearance height above the riser flange is approximately $8^{\prime}-3^{\prime \prime}$ in each pit.

The SY-Farm consists of three DSTs that have been in operation since 1980. One annulus pump is available for emergency pumping in the SY-Farm. This pump is currently in the 241-SY-03B Annulus Pump Pit and has not been operated or maintained for more than 15 years. The pump, PTX-4, has a design point of $100 \mathrm{gpm}$ at a head of $150 \mathrm{ft}$. In addition, the pump has a length of $46^{\prime}-2-1 / 2^{\prime \prime}$ and extends to within 2-5/16" of the bottom of the tank. The remaining two annulus pump pit risers are open and no spare pump is available. The clearance height above the riser flange is approximately $8^{\prime}-3^{\prime \prime}$ in each pit.

\subsubsection{Maintenance Program}

Preventive maintenance is currently not done on the existing annulus pumps. It is assumed that the pump shaft will be turned at the time it is being set up for an emergency pumping operation, but no other maintenance will be done. This adds a significant amount of reliability risk to this alternative since the pumps have not been maintained or operated for at least 14 years (APFarm). It has been the practice in the past to require a run-in test per HS-V-0030 if a pump had been in storage for more than 90 days, however, this did not apply to installed pumps. A run-in test consists of operating the pump at its rated flow for a designated duration. Discharge pressure, flow, amperage, motor bearing temperature, and vibration are measured and compared with the acceptance criteria specified for the pump. A run-in facility capable of testing fulllength pumps is not currently available at the Hanford Site.

\subsubsection{Cost}

The only initial cost for this alternative will be the cost required to install the emergency pump (estimated \$46,000). This cost will only be incurred in the event of a tank leak. Establishing an budget for this amount is probably not warranted. For the AW-Farm, an annual maintenance cost will be required for storage of the AW-Farm pump ( $\$ 1,000 /$ year $)$. For the AW-Farm only, an additional cost of $\$ 10,000$ to $\$ 20,000$ will be incurred to perform modifications and run in.

The life-cycle cost of this alternative includes $\$ 400,000$ for removal and disposal of one contaminated pump. It was assumed that this cost would occur in year five of the 20 -year life cycle. The total life-cycle cost for Alternative 1 has a present and annual value of $\$ 381,000$ and $\$ 26,400$, respectively (see Appendix C). 


\subsubsection{Environmental Issues}

The regulations ( 40 CFR) require that waste be removed from a secondary containment system within twenty-four hours, or in as timely a manner as is possible. This alternative cannot support the 24-hour response. It has been estimated that the time to mobilize a crew to move an existing pump from one annulus to another and have it operational will be two weeks (LMHC 1998). In addition, with the vertical turbine pump currently used, the heel remaining after pumping is complete will be at least 12 inches $(5,200$ gal). The annulus ventilation system will not be operational due to submergence of the ventilation air slots in the insulating concrete. A remaining heel level greater than approximately 5 -in will begin to diminish the ventilation flow rate. At a heal level of approximately 12 -in, ventilation flow will cease due to the limited vacuum capacity of exhausters. This amount of waste heel provides additional risk. Small tank leaks cannot be addressed effectively with this alternative.

\subsubsection{ALARA Considerations}

For this alternative, it is assumed that the spare annulus pump is not in the DST that has leaked. Therefore, operators will be required to remove the cover blocks from the annulus pit that contains the spare pump, and remove the pump. Although the pit should be clean, the operators will be exposed to higher than background radiation levels since the cover blocks will be removed. In addition, the potential exists that the pump is stored in the leaking DST, however, due to no preventive maintenance program, the pump will not operate. This will increase the exposure since a contaminated pump may have to be removed, disposed of, and a new pump installed. For these reasons, Alternative 1 has a poor rating for ALARA considerations.

\subsubsection{Pros and Cons}

The following is a list of the pros and cons associated with Alternative 1:

- Pros

- Low initial cost

- Lowest annual maintenance costs

- Pumps stored vertically in a warm, clean, and dry environment.

- Cons

- Lowest reliability

- $\quad$ Poor plump down capability (heel estimated at 12-in or approximately 5,200 gal)

- Slow pumping response time due to the need to open two pits to move a pump from the installed tank to another

- $\quad$ Poor ALARA characteristics due to low reliability and the need to work in two pits 
- Not favorably viewed by regulators due to environmental issues

- Highest potential for pump failure in waste that would result in high disposal costs.

\subsection{Alternative 2 - Periodic Pump Removal and Run-In}

Alternative 2 maintains the current DST annulus pumping scheme of providing one vertical turbine pump in a designated tank at each tank farm. Under the alternatives, a preventive maintenance program consisting of periodic pump removal and performance of full run-in tests would be implemented. As with the "Continue Status Quo" alternative (Alternative 1), the annulus pump will need to be moved if the leaking primary tank of a DST is other than the one containing the pump.

\subsubsection{Configuration/Architecture}

The configuration for each tank farm is the same as that addressed in Section 3.1.1 for Alternative 1. The spare pump for the AW-Farm will need to be prepared for installation and maintenance and a run-in facility capable of handling full-length pumps (approximately $47 \mathrm{ft}$ ) will need to be provided for this alternative.

\subsubsection{Maintenance Program}

The preventive maintenance program will require run-in testing every five years of all six DST annulus pumps. The run-in test will consist of operating the pump at its rated flow for a designated duration. Discharge pressure, flow, amperage, motor bearing temperature, and vibration will be measured and compared with the acceptance criteria specified for the pump. This maintenance program will reduce the risk of the pump not operating when it is needed, but will require establishment of a run-in facility onsite. The 272E Pipe Shop has a 50-ft deep test pit, however, the facility was closed down in FY 1996.

\subsubsection{Cost}

The initial cost of this alternative (estimated $\$ 337,000$ ) will include the cost to modify an existing spare pump for the AW-Farm. Forty-six thousand dollars of this amount for emergency pump installation will only be needed in the event of a tank leak. Establishing budget for this cost is probably not warranted. In addition, Alternative 2 includes $\$ 200,000$ to establish an onsite run-in facility and installs the AW-Farm annulus pump in a designated DST. The annual maintenance cost (estimated $\$ 61,200$ ) will include the removal and run-in testing of each of the six tank farm annulus pumps on a five-year basis (see Appendix B). 
The life-cycle cost of this alternative includes $\$ 400,000$ for removal and disposal of one contaminated pump. It was assumed that this cost would occur in year 15 of the 20 -year life cycle. Due to having the highest initial and annual costs, Alternative 2 has the highest life-cycle cost. The total life-cycle cost for Alternative 2 has a present and annual value of $\$ 1,393,000$ and $\$ 96,700$, respectively (see Appendix C).

\subsubsection{Environmental Issues}

The environmental issues for this alternative are the same as that addressed in Section 3.1.4 for Alternative 1. As with Alternative 1, approximately 5,200 gal of waste would be left in the annulus. Small tank leaks cannot be addressed effectively with this alternative.

\subsubsection{ALARA Considerations}

The ALARA considerations for Alternative 2 will be similar to those of Alternative 1 . Increased exposure will be incurred because of the requirement to remove the annulus pumps every five years. However, the reduced likelihood of contaminated pump failure, removal and disposal results in a net reduction in exposure potential for operators over Alternatives 1 and 3.

\subsubsection{Pros and Cons}

The following is a list of the pros and cons associated with Alternative 2:

- Pros

- $\quad$ Higher reliability than Alternative 1 or 3

- $\quad$ Pumps stored vertically in a warm, clean, and dry environment.

- Cons

- Highest initial, annual, and life-cycle costs

- Poor pump down capability (heel estimated at 12-in or approximately 5,200 gal)

- Slow pumping response time due to the need to open two pits to move a pump from the installed tank to another

- $\quad$ Relatively high ALARA concerns due to the need to work in two pits.

\subsection{Alternative 3 - Periodic In-Place Limited Maintenance}

Alternative 3 maintains the current DST annulus pumping scheme of providing one vertical turbine pump in a designated tank at each tank farm. A preventive maintenance program consisting of periodic in-place limited maintenance without a run-in test would be implemented and the annulus pump for the AW Farm will be fabricated and stored in the 273-EA laydown yard. As with the "Continue Status Quo" altemative (Alternative 1), the annulus pump will need 
to be moved if the leaking primary tank of a DST is other than the one containing the pump.

\subsubsection{Configuration/Architecture}

The configuration for each tank farm is the same as that addressed in Section 3.1.1 for Alternative 1, "Continue Status Quo". As with Alternative 1, a spare pump will need to be prepared for installation in the AW-Farm.

\subsubsection{Maintenance Program}

The preventive maintenance program will perform maintenance on the pump motor and bearings and will manually turn the shaft every five years for all six DST annulus pumps. This maintenance program will lower the risk of the pump not operating when it is needed, but will not assure that pump components such as shaft, bearings and impeller are in good operating condition. It will require periodic operator entry into the annulus pump pits.

\subsubsection{Cost}

The initial cost of this alternative will include the cost to modify an existing spare pump for the AW-Farm (estimated $\$ 121,000$ ). Forty-six thousand dollars of this amount for emergency pump installation will only be included in the event of a tank leak. The annual maintenance cost $(\$ 21,200)$ will include removal of the cover blocks and pit entry every five years for each of the six tank farms besides the cost for motor and bearing replacement (see Appendix B).

The life-cycle cost of this alternative includes $\$ 400,000$ for removal and disposal of one contaminated pump. It was assumed that this cost would occur in year ten of the 20 -year life cycle. The total life-cycle cost for Alternative 3 has a present and annual value of $\$ 678,000$ and $\$ 47,000$, respectively (see Appendix C).

\subsubsection{Environmental Issues}

The environmental issues associated with this alternative are the same as that addressed in Section 3.1.4 for Alternative 1. As with Alternative 1, approximately 5,200 gal of waste will be left in the annulus. Best case pumping time is estimated to be two to three weeks. Small tank leaks cannot be addressed effectively with this alternative.

\subsubsection{ALARA Considerations}

The ALARA considerations for Alternative 3 will be similar to those for Alternative 2. The potential for exposure to operators will be greater than Alternative 1 due to the required periodic pit entries. For these reasons, Alternative 3 has a low rating for ALARA considerations. 
to be moved if the leaking primary tank of a DST is other than the one containing the pump.

\subsubsection{Configuration/Architecture}

The configuration for each tank farm is the same as that addressed in Section 3.1.1 for Alternative 1, "Continue Status Quo". As with Alternative 1, a spare pump will need to be prepared for installation in the AW-Farm.

\subsubsection{Maintenance Program}

The preventive maintenance program will perform maintenance on the pump motor and bearings and will manually turn the shaft every five years for all six DST annulus pumps. This maintenance program will lower the risk of the pump not operating when it is needed, but will not assure that pump components such as shaft, bearings and impeller are in good operating condition. It will require periodic operator entry into the annulus pump pits.

\subsubsection{Cost}

The initial cost of this alternative will include the cost to modify an existing spare pump for the AW-Farm (estimated $\$ 121,000$ ). Forty-six thousand dollars of this amount for emergency pump installation will only be included in the event of a tank leak. The annual maintenance cost $(\$ 21,200)$ will include removal of the cover blocks and pit entry every five years for each of the six tank farms besides the cost for motor and bearing replacement (see Appendix B).

The life-cycle cost of this alternative includes $\$ 400,000$ for removal and disposal of one contaminated pump. It was assumed that this cost would occur in year ten of the 20-year life cycle. The total life-cycle cost for Alternative 3 has a present and annual value of $\$ 678,000$ and $\$ 47,000$, respectively (see Appendix C).

\subsubsection{Environmental Issues}

The environmental issues associated with this alternative are the same as that addressed in Section 3.1.4 for Alternative 1. As with Alternative 1, approximately 5,200 gal of waste will be left in the annulus. Best case pumping time is estimated to be two to three weeks. Small tank leaks cannot be addressed effectively with this alternative.

\subsubsection{ALARA Considerations}

The ALARA considerations for Alternative 3 will be similar to those for Alternative 2. The potential for exposure to operators will be greater than Alternative 1 due to the required periodic pit entries. For these reasons, Alternative 3 has a low rating for ALARA considerations. 


\subsubsection{Pros and Cons}

The following is a list of the pros and cons associated with Alternative 3:

- $\quad$ Pros

- $\quad$ Higher reliability than Alternative 1

- Low initial costs

- Pumps stored vertically in a warm, clean, and dry environment.

- Cons

- $\quad$ Less reliability than Alternatives 2, 4, or 5

- $\quad$ Poor plump down capability (heel estimated at 12 -in or approximately 5,200 gal)

- $\quad$ High life-cycle costs due to annual maintenance and disposal

- $\quad$ Regular access required to annulus pits with limited increase in reliability

- Slow pumping response time due to the need to open two pits to move a pump from the installed tank to another

- Poor ALARA considerations due to low reliability and the need to work in two pits.

\subsection{Alternative 4 - Uninstalled Ready Spares}

Alternative 4 describes a new DST annulus pumping scheme by providing four spare submersible pump assemblies ready for installation. One pump will support the AY- and AZFarm configurations, one pump will be configured for the AN-107 DST, one pump will support the other AN-Farm tanks, and one will support the AP-, AW-, and SY-Farms (see Figure A-1 in Appendix A). These pumps will not be installed in an annulus pit until they are needed. Instead, they will be stored indoors in a facility such as $2101-\mathrm{M}$.

\subsubsection{Configuration/Architecture}

The existing annulus pumps in the AN-, AP-, AY-, AZ-, and SY-Farms will be removed. Four new pump assemblies will be designed and fabricated using BJM RX1500SS stainless steel submersible pumps. The pumps will have a capacity of approximately $40 \mathrm{gpm}$ at $60 \mathrm{ft}$ of head. The pump that supports the AY- and AZ-Farms will have a length of 46'-4" while the pump that supports the AN-107 DST will have a length of 46'-8". The pump that supports the other ANFarm tanks will have a length of $46^{\prime}-5^{\prime \prime}$, and the pump for the AP-, AW-, and SY-Farms will have a length of $46^{\prime}-4 "$. Although two of the pumps have the same length, a different flange mounting plate is required. These pumps will be stored in an existing indoor facility. 


\subsubsection{Maintenance Program}

The spare pumps will be maintained in a ready state by providing monthly rotation of the pumps in storage and requiring a run-in test every five years for all four pumps. This maintenance program will minimize the risk of the pumps not operating when they are needed. In addition, a full length run-in facility will not be required for the pumps.

\subsubsection{Cost}

The initial cost of this alternative $(\$ 212,000)$ includes the cost to design and fabricate four new pumps and the cost to remove the five existing annulus pumps. Thirty thousand dollars of this amount for emergency pump installation will only be required in the event of a tank leak. In addition, the initial cost includes minor electrical modifications to each DST annulus pit. The annual maintenance cost $(\$ 3,000)$ would include the monthly rotation and the run-in tests every five years (see Appendix B).

The life-cycle cost of this alternative includes $\$ 40,000$ for removal and disposal of one contaminated pump. It was assumed that this cost would occur in year fifteen of the 20 -year life cycle. The lower cost of disposal as compared with Alternatives 1, 2, and 3 is because the disposal cost is based on volume. The submersible pump can be cut off the pump assembly and buried in a 55-gal drum while the vertical turbine pumps require full-length, high-volume disposal. Due to the lower maintenance and disposal costs, the total life-cycle cost for Alternative 4 has a present and annual value of $\$ 269,000$ and $\$ 18,600$, respectively (see Appendix C).

\subsubsection{Environmental Issues}

There are no significant environmental issues for Alternative 4. The readiness of the spare pumps will reduce the response time significantly (approximately one week) by not requiring the moving of a pump from one pit to another. The only factor that will slow the response time is the mobilization of a crane to remove cover blocks and install the pump. In addition, the BJM submersible pump will have an estimated remaining heel of 3 in. The annulus vent system will be operational once the annulus level is pumped below approximate $12 \mathrm{in}$. This remaining heel will be equal to approximately 1,000 gal of waste.

\subsubsection{ALARA Considerations}

The ALARA considerations for Alternative 4 will be better than Alternatives 1, 2, and 3. Only one pit entry in the event of a leak in the tank is required and there is no potential for exposure to operators during maintenance. For these reasons, Alternative 4 has a high rating for ALARA considerations. 


\subsubsection{Pros and Cons}

The following is a list of the pros and cons associated with Alternative 4:

Pros $\quad$ Higher reliability than Alternative 1 or 3

- Flexible installation into affected annulus

- $\quad$ Fewer spare parts to maintain and stage

- Better heel removal than Alternatives 1, 2, or 3 (heel estimated at approximately 3 -in or $1,000 \mathrm{gal}$ )

- Quicker response time than Alternatives 1,2, or 3 if leak is in a tank other than the one into which the pump is installed

- $\quad$ Lower volume of mixed waste if pump fails than Alternatives 1,2 , or 3

- $\quad$ Easily maintained

- Good ALARA characteristics

- Doesn't require full length run-in

- Better procurement/fabrication time than Alternatives 1, 2, or 3

- Pumps can be stored in a warm, clean, dry environment.

- Cons

- $\quad$ Submersible pump is less desirable than vertical turbine pump for long-term radiation exposure (only short-term exposure is expected and radiation resistant elastomers are available).

\subsection{Alternative 5 - Expanded Mission of SST Emergency Pumping Trailer}

The Single Shell Tank Stabilization group within LMHC SST Farms has a trailer mounted emergency pumping system to support quick pumping of SSTs if warranted. The overall system and process for emergency pumping of SSTs is contained in Single-Shell Tank Leak Emergency Pumping Guide, HNF-SD-WM-AP-005, Rev. 7. The primary components of the existing system are listed below:

- A field-length adjustable riser mounted submersible pump

- A field-length adjustable riser mounted jet pump assembly

- A field length adjustable weight factor dip tube assembly

- A Pumping and Instrument Control Skid equipped with power racks including: disconnects, breakers, $480 / 120 \mathrm{~V}$ transformer, welder plug hookup system, a water tank for system flushing and priming, weight factor instrumentation, and an air compressor

- Flammable gas monitoring system

- Provisions for connection to the master pump shutdown system

- $\quad$ Flexible jumper assemblies 
- $\quad$ Emergency Pumping Equipment Storage Trailer, $45 \mathrm{ft}$ semi-trailer (HO-64-05192)

- An intrinsically safe portable exhauster.

Alternative 5 uses an annulus pumping scheme similar to that of Alternative 4 except that it expands upon the use of the existing SST emergency pumping trailer which will require some enhancement to optimize it for DST use. Existing transfer lines will continue to be used for this alternative. Like Alternative 4, a maintenance program will be established that includes periodic run-in of the pumps without the need for a dedicated run-in facility. The main differences between Alternative 4 and 5 are:

1) Only two pumps will be maintained and the design of the pumps will allow for the length to be quickly adjusted in the field.

2) This altemative will also provide a low-volume air-operated Hydro-Star reciprocating pump on each assembly which will substantially reduce the volume of heel remaining after annulus pumping.

3) All components needed will be co-located in a single location (trailer) that can be quickly moved to the emergency site.

\subsubsection{Configuration/Architecture}

Like Alternative 4, the existing annulus pumps in the AN-, AP-, AY-, AZ-, and SY-Farms will be removed and the new submersible pump assembly will be designed and fabricated using a BJM RX1500SS stainless steel submersible pump. The varying pump lengths required will be supported by having removable spool pieces in the discharge piping that correspond to the differing lengths. The other difference with this alternative is that an air operated Hydro-Star reciprocating piston pump will be mounted next to the submersible pump and suspended from the same riser flange. The Hydro-Star pump can be adjusted to pump from $0.1 \mathrm{gpm}$ at 1 stroke per minute to greater than $4.5 \mathrm{gpm}$ at 60 strokes per minute. The air motor will be located in the annulus pit to assure that any potential leakage at the shaft packing is contained. In addition, a pressure relief valve at the pump discharge port will be installed to assure that excessive pressures are not a concern if the discharge line is closed with the pump operating. Air usage at maximum flow is approximately $6 \mathrm{scfm}$. Figure A-1 in Appendix A depicts this configuration.

\subsubsection{Maintenance Program}

The spare submersibles and Hydro-Star pumps will be maintained in a ready state by requiring a monthly rotation of the pumps in storage and requiring a run-in test every five years for all four pumps. Like Alternative 4, this maintenance program will minimize the risk of the pumps not operating when they are needed and will not require a dedicated run-in facility onsite. 


\subsubsection{Cost}

The initial cost of this alternative $(\$ 186,000)$ is comparable to that of Alternative 4. Thirty thousand dollars of this amount for emergency pump installation will only be required in the event of a tank leak. The two Hydro-Star pumps are slightly less costly than two more submersible pumps, however, design and engineering cost will be slightly higher. In addition, the only electrical modifications required will be for the trailer since it will provide the interface to each farm. The annual recurring costs $(\$ 3,000)$ will be the same as Alternative 4 .

The life-cycle cost of this alternative includes $\$ 40,000$ for removal and disposal of one contaminated pump. It was assumed that this cost would occur in year 15 of the 20 -year life cycle. Like Alternative 4, the submersible and Hydro-Star pump assembly can be cut off the pump assembly and be buried in a 55-gal drum. Alternative 5 has the lowest life-cycle. The total life-cycle cost for Alternative 5 has a present and annual value of $\$ 244,000$ and $\$ 16,900$, respectively (see Appendix C).

\subsubsection{Environmental Issues}

Alternative 5 has no significant environmental issues. The readiness of the spare pumps and the mobility of the trailer gives this alternative the quickest response time. As with Alternative 4, the only factor that will limit this is the mobilization of a crane to remove cover blocks and install the pump. This alternative is considered to have the fastest response time. In addition, the Hydro-Star pump can pump the annulus down to a remaining heel of approximately $1 / 2$ in. This will not only allow the annulus vent system to be operational, but will result in only approximately $200 \mathrm{gal}$ of waste remaining in the annulus.

\subsubsection{ALARA Considerations}

The ALARA considerations for Alternative 5 will be identical to those of Alternative 4. Only one pit entry is required and there is no potential for exposure exist to operators during maintenance. For these reasons, Alternative 5 has a high rating for ALARA considerations.

\subsubsection{Pros and Cons}

The following is a list of the pros and cons associated with Alternative 5:

- Pros

- $\quad$ Higher reliability than Alternative 1 or 3

- Flexible installation into affected annulus

- $\quad$ Fewer spare parts to maintain and stage

- Better heel removal than Alternatives 1, 2, 3, or 4 (heel estimated at $1 / 2$-in or 


approximately 200 gal)
Quicker response time than Alternatives $1,2,3$, or 4 if leak is in a tank other than
the one into which the pump is installed. System is mobile on a trailer ready to go
- Lower volume of mixed waste if pump fails than Alternatives 1,2 , or 3
- $\quad$ Highly adjustable flow rate with Hydro-Star pump for final liquid removal
- $\quad$ Easily maintained
- $\quad$ Good ALARA characteristics
- $\quad$ Doesn't require full length run-in facility
- $\quad$ Better procurement/fabrication time than Alternatives 1,2 , or 3
- $\quad$ Pumps can be stored in a clean, dry environment.

- Cons

- Hydro-Star pump has limited solids pumping capabilities

- Submersible pump is less desirable than vertical turbine pump for long-term radiation exposure (only short-term exposure is expected and radiation resistant elastomers are available).

\subsection{ALTERNATIVE EVALUATION}

Once the weighting criteria were established and each alternative described, the alternatives were evaluated against the criteria to obtain a relative numerical score which reflected how well that alternative met the criteria. To facilitate the analysis, a comparative score card was compiled (see Table 2). In addition, a cost comparison summary of the alternatives is provided in Table 3. The following discussions summarize the key results of the alternative evaluation sorted by criteria (see Table 2 for numerical rankings).

\subsection{Acceptability to Regulators}

The Emergency Trailer (Alternative 5) scores the highest due to the low remaining heel and the quickest response time. The Uninstalled Spares (Alternative 4) scores lower since the remaining heel and response time are higher, but assumes that the alternative would still be acceptable to regulators. The Periodic Maintenance and Limited Maintenance alternatives (Alternatives 2 and 3 , respectively) are much less acceptable. However, due to the increased reliability, the Periodic Maintenance (Alternative 2) alternative is rated higher. Alternatives 1, 2, and 3 are less desirable to regulators due to the larger waste heel remaining after pumping. The Continue Status Quo alternative (Alternative 1) would be the least desirable to regulators. 


\subsection{Initial Cost}

All of the alternatives require some initial costs. The rating for this criterion was done by assigning the highest score (100) to the lowest cost alternative and the lowest score $(0)$ to the highest cost alternative. The remaining alternatives were linearly interpolated between these two alternatives (see Table 3).

\subsection{Life-Cycle Cost}

The life-cycle cost was rated in the same manner as the initial cost. This rating was done with and without the disposal cost, however, the overall alternative ranking was not affected by the disposal cost (see Table 3). Each alternative assumes one pump failure and disposal during a 20 year life cycle but no final decommissioning and disposal costs. The time at which the disposal cost would be incurred during the life-cycle was varied to reflect relative reliability of the alternative.

\subsection{Flexibility}

The Emergency Trailer (Alternative 5) is very flexible since the length of the pumps is readily adjustable, the system is easily moved to the different tank farms, and all needed equipment is co-located in a single trailer. The Uninstalled Spares (Alternative 4) scores slightly lower since the pumps are set for specific lengths and adapter flanges, and supporting equipment is not as readily available and co-located as the trailer system. The remaining three alternatives received much lower rankings since the pumps are installed in a specific annulus pump pit and in most cases considerable modifications would be required for installation in the leaking tank. The Periodic Maintenance alternative (Alternative 2) is ranked higher than Alternatives 1 and 3 higher since the pumps will be regularly removed and work plans will be in place.

\subsection{ALARA Considerations}

The Emergency Trailer (Alternative 5) and Uninstalled Spares (Alternative 4) are rated the same because only one pit entry will be required--and then only in the event of a primary tank leak. Alternatives 2 and 3 received much lower ratings since two pit entries are required to install the annulus pump and periodic pit access is required for maintenance. The Continue Status Quo alternative (Alternative 1) is rated the lowest since the possibility exists that a dead-on-arrival pump could be contaminated and require removal.

\subsection{Reliability}

The Emergency Trailer (Alternative 5), the Uninstalled Spares (Alternative 4), and the Periodic Maintenance alternatives (Alternative 2 ) are all highly reliable. The Periodic Maintenance 
(Alternative 2) is rated lower because of the difficulty in maintaining the pumps. The Limited Maintenance alternative (Alternative 3) provides a marginally acceptable level of reliability, but not as good as the previous three alternatives. Finally, the Continue Status Quo alternative (Alternative 1) provides the least degree of reliability because no preventive maintenance is performed and the pumps have been unused for more than 14 years.

Table 2. Alternative Rating Evaluation

\begin{tabular}{|c|c|c|c|c|c|c|}
\hline Criteria & $\begin{array}{c}\text { Possible } \\
\text { Score }\end{array}$ & $\begin{array}{l}\text { Alt. 1 } \\
\text { Continue } \\
\text { Status } \\
\text { Quo } \\
\end{array}$ & $\begin{array}{c}\text { Alt. } 2 \\
\text { Periodic } \\
\text { Maint. }\end{array}$ & $\begin{array}{c}\text { Alt.3 } \\
\text { Limited } \\
\text { Maint. }\end{array}$ & $\begin{array}{c}\text { Alt. } 4 \\
\text { Uninstalled } \\
\text { Spares }\end{array}$ & $\begin{array}{c}\text { Alt. } 5 \\
\text { Emergency } \\
\text { Trailer }\end{array}$ \\
\hline \multicolumn{7}{|c|}{ Acceptability to Regulators } \\
\hline $\begin{array}{l}\text { Approaches } \\
\text { regulatory } \\
\text { requirements (pump in } \\
24 \text { hours or ASAP, } \\
\text { completely pump } \\
\text { annulus, very slight } \\
\text { risk to environment, } \\
\text { etc.) }\end{array}$ & $75-100$ & & & & 80 & 90 \\
\hline $\begin{array}{l}\text { Will provide } \\
\text { reasonably negotiable } \\
\text { response in terms of } \\
\text { response time, degree } \\
\text { of pumping, and risk }\end{array}$ & $50-74$ & & 60 & 50 & & \\
\hline $\begin{array}{l}\text { Will be highly } \\
\text { controversial }\end{array}$ & $0-49$ & 15 & & & & \\
\hline \multicolumn{7}{|l|}{ Initial Cost } \\
\hline Low & $75-100$ & 100 & & & & \\
\hline Moderate & $50-74$ & & & 74 & & \\
\hline High & $0-49$ & & 0 & & 43 & 52 \\
\hline \multicolumn{7}{|c|}{ Life-Cycle Cost (less initial cost) } \\
\hline Low & $75-100$ & & & & 100 & 100 \\
\hline Moderate & $50-74$ & 71 & & & & \\
\hline High & $0-49$ & & 0 & 47 & & \\
\hline
\end{tabular}




\begin{tabular}{|c|c|c|c|c|c|c|}
\hline \multicolumn{5}{|c|}{$\begin{array}{l}\text { DOUBLE-SHELl TANK ANNULUS PUMPING ALTERNATIVE } \\
\text { EVALUATION }\end{array}$} & \multicolumn{2}{|c|}{$\begin{array}{r}\text { Report No. 9905303-001, Rev. } 0 \\
\text { March } 1999 \\
\end{array}$} \\
\hline Criteria & $\begin{array}{l}\text { Possible } \\
\text { Score }\end{array}$ & $\begin{array}{c}\text { Alt. 1 } \\
\text { Continue } \\
\text { Status } \\
\text { Quo } \\
\end{array}$ & $\begin{array}{l}\text { Alt. } 2 \\
\text { Periodic } \\
\text { Maint. }\end{array}$ & $\begin{array}{l}\text { Alt.3 } \\
\text { Limited } \\
\text { Maint. }\end{array}$ & $\begin{array}{l}\text { Alt. } 4 \\
\text { Uninstalled } \\
\text { Spares }\end{array}$ & $\begin{array}{c}\text { Alt. } 5 \\
\text { Emergency } \\
\text { Trailer }\end{array}$ \\
\hline \multicolumn{7}{|l|}{ Flexibility } \\
\hline $\begin{array}{l}\text { Adapts readily to all } \\
\text { installations and } \\
\text { possible leak } \\
\text { scenarios }\end{array}$ & $75-100$ & & & & 75 & 90 \\
\hline $\begin{array}{l}\text { May be used in most } \\
\text { circumstances with } \\
\text { acceptable results }\end{array}$ & $50-74$ & & 50 & & & \\
\hline $\begin{array}{l}\text { Can only be used in } \\
\text { limited circumstances }\end{array}$ & $0-49$ & 40 & & 40 & & \\
\hline \multicolumn{7}{|l|}{ ALARA } \\
\hline $\begin{array}{l}\text { Achieves minimal } \\
\text { radiation and chemical } \\
\text { exposure }\end{array}$ & $75-100$ & & & & & \\
\hline $\begin{array}{l}\text { Is consistent with } \\
\text { normal ALARA } \\
\text { principles }\end{array}$ & $50-74$ & & & & 70 & 70 \\
\hline $\begin{array}{l}\text { Raises significant } \\
\text { ALARA concerns }\end{array}$ & $0-49$ & 10 & 40 & 30 & & \\
\hline \multicolumn{7}{|l|}{ Reliability } \\
\hline $\begin{array}{l}\text { Provides high degree } \\
\text { of reliability }\end{array}$ & $70-100$ & & 80 & & 90 & 90 \\
\hline $\begin{array}{l}\text { Provides an } \\
\text { acceptable degree of } \\
\text { reliability }\end{array}$ & $60-69$ & & & 65 & & \\
\hline $\begin{array}{l}\text { Provides least degree } \\
\text { of reliability }\end{array}$ & $30-59$ & 35 & & & & \\
\hline$\underset{\text { CORPORATION }}{\mathbf{A R E S}}$ & & & & & PAGE & MBER \\
\hline
\end{tabular}


Table 3. Alternative Cost Comparison Summary

\begin{tabular}{|c|c|c|c|c|c|}
\hline & Initial & Annual & $\begin{array}{l}\text { Decontamination \& } \\
\text { Decommissioning }\end{array}$ & Annual LC & Less Initial \\
\hline & Cost & Maintenance & (D\&D) & $\begin{array}{c}\text { With } \\
\text { Disposal }\end{array}$ & $\begin{array}{l}\text { Without } \\
\text { Disposal }\end{array}$ \\
\hline $\begin{array}{l}\text { Alternative 1: } \\
\text { Continue Status Quo }\end{array}$ & $\$ 46,000$ & $\$ 1,000$ & $\$ 400,000$ & $\$ 23,330$ & $\$ 956$ \\
\hline $\begin{array}{l}\text { Alternative 2: } \\
\text { Periodic Pump Removal } \\
\text { and Run-in }\end{array}$ & $\$ 337,000$ & $\$ 61,200$ & $\$ 400,000$ & $\$ 70,040$ & $\$ 58,497$ \\
\hline $\begin{array}{l}\text { Alternative 3: } \\
\text { Periodic In-place } \\
\text { limited maintenance }\end{array}$ & $\$ 121,000$ & $\$ 21,200$ & $\$ 400,000$ & $\$ 38,913$ & $\$ 20,264$ \\
\hline $\begin{array}{l}\text { Alternative 4: } \\
\text { Uninstalled Ready } \\
\text { Spares }\end{array}$ & $\$ 212,000$ & $\$ 3,000$ & $\$ 40,000$ & $\$ 4,421$ & $\$ 2,867$ \\
\hline $\begin{array}{l}\text { Alternative 5: } \\
\text { Expanded Mission of } \\
\text { SST Emergency } \\
\text { Pumping Trailer }\end{array}$ & $\$ 186,000$ & $\$ 3,000$ & $\$ 40,000$ & $\$ 4,421$ & $\$ 2,867$ \\
\hline
\end{tabular}

* Life-cycle costs are reported less initial costs since the alternative rating evaluates both initial and life-cycle cost measures separately and if not removed from the latter, initial cost would be counted twice.

\subsection{SUMMARY/RECOMMENDATIONS}

The purpose of this report was to evaluate alternatives for annulus pumping systems in case of a primary tank leak. The alternatives were rated against consistent criteria to assure a fair comparison and then ranked based on the weighting set for each criteria.

Alternatives 1 through 3 maintain the current DST annulus pumping scheme of providing one vertical turbine pump stored in a designated tank annulus. These alternatives vary primarily in their preventive maintenance programs. Alternatives 4 and 5 establish a new pumping scheme of providing readily available submersible pumps that will be installed only if and when needed. The primary difference between Alternatives 4 and 5 is in their capabilities to reduce the heel remaining in the annulus after pumping and location and staging of the emergency pumping equipment. 
The analyses of the five alternatives have been summarized in Table 4. Table 4 lists each alternative's score for each criterion, multiplied by the weighting factor, then summed to produce a cumulative score for each alternative. Based on its overall ranking of Emergency Trailer (Alternative 5) is the preferred alternative and will provide the most reliable and effective annulus pumping system for the DSTs. This alternative ranks the highest against all of the criteria except initial cost, however, the initial cost is only $\$ 135,000$ different from the least cost alternative. The total initial cost for Alternative 5 is approximately $\$ 180,000$.

Table 4. Summary of Alternative Comparison Results (Ranked by Total Score ${ }^{\mathrm{t}}$ )

\begin{tabular}{|c|c|c|c|c|c|}
\hline Criteria & $\begin{array}{c}\text { Alt. } 1 \\
\text { Continue } \\
\text { Status Quo }\end{array}$ & $\begin{array}{c}\text { Alt. } 2 \\
\text { Periodic } \\
\text { Maintenance }\end{array}$ & $\begin{array}{c}\text { Alt. } 3 \\
\text { Limited } \\
\text { Maintenance }\end{array}$ & $\begin{array}{c}\text { Alt. } 4 \\
\text { Uninstalled } \\
\text { Spares }\end{array}$ & $\begin{array}{c}\text { Alt. } 5 \\
\text { Emergency } \\
\text { Trailer }\end{array}$ \\
\hline $\begin{array}{l}\text { Acceptability to } \\
\text { Regulators }\end{array}$ & 3.90 & 15.60 & 13.00 & 20.80 & 23.40 \\
\hline Initial Cost & 6.00 & 0 & 4.44 & 2.58 & 3.12 \\
\hline $\begin{array}{l}\text { Life-Cycle Cost } \\
\text { (less initial cost) }\end{array}$ & 12.07 & 0 & 7.99 & 17.00 & 17.00 \\
\hline Flexibility & 5.60 & 7.00 & 5.60 & 10.50 & 12.60 \\
\hline ALARA & .90 & 3.60 & 2.70 & 6.30 & 6.30 \\
\hline Reliability & 9.80 & 22.40 & 18.20 & 25.20 & 25.20 \\
\hline TOTAL $^{3}$ & 38 & 49 & 52 & 82 & 88 \\
\hline
\end{tabular}

\section{Notes:}

1. Total Score $=$ Criteria Weighting Factor X Alternative Rating

2. Includes disposal cost for one contaminated pump.

3. Total Score rankings are consistent whether contaminated equipment disposal costs are included or not. 


\subsection{REFERENCES}

40CFR, Part 265.193 (c)(4), Containment and detection of releases.

NIST 1998, Building Life-Cycle Cost (BLCC) Program, Version 4.6, National Institute of Standards and Technology, Washington, D.C.

LMHC 1998, Double-Shell Tank Emergency Pumping Guide, HNF-3484, Rev. 0, Lockheed Martin Hanford Corporation, Richland, Washington.

WHC 1992, Tank Farms Pumping Equipment List, WHC-SD-WM-RPT-025, Rev. 1, Westinghouse Hanford Company, Richland, Washington. 
Double-Shell Tank annulus Pumping Alternative

Report No. 9905303-001, Rev. 0

EVALUATION March 1999

Appendix A

Double-Shell Tank Annulus Pumping Data 


\section{A1.0 COMMON DST ANNULUS SYSTEMS}

All DSTs have an annulus pump pit located directly above the annulus. The pit has an inside dimension of $5-\mathrm{ft}$ by $5-\mathrm{ft}$ and consists of a 12 -in riser connected directly to the annulus. A rigid or flex jumper assembly connects the pump outlet to a 2 -in process waste line encased in a 4-in encasement. Unless otherwise noted, the process waste line terminates at the Central Pump Pit of the tank. Figure A-1 in Appendix A shows a typical cross-section of the DST annulus pump pit.

Each DST has an annulus ventilation system. This system works by running 4-in supply lines in the annulus of the DSTs. The supply lines run down the walls of the annulus and then are embedded in the insulating concrete that provides the base for the primary tank. The air is directed to a 3-ft diameter ring at the center of the tank that then forces air to return in channels cut in the insulating concrete. This provides heat removal under the primary tank and up the walls of the annulus to the annulus exhaust. If a DST leaks waste into the annulus, the annulus ventilation system will be inoperable until waste is removed to a level below the return channels because the annulus exhaust fans can only pull a vacuum of approximately 4 -in to 6 -in of water. The level of the channels varies with each farm, but only if the waste level is less than 4-in will each annulus vent system be operable. The remaining heel left after pumping the anmulus will determine whether the annulus vent system will be operable. 


\section{Appendix B}

Estimated Initial, Maintenance, and D\&D Costs for Alternatives 


\section{ESTIMATED ACTIONS/COSTS FOR EACH ALTERNATIVE}

\section{Alternative 1: Continue Status Quo \\ Initial Cost}

- Emergency Pumping Installation

- Work plan ................................. $\$ 3,000$

- Crane, remove/replace cover block on two pits . . . . . . . . . . . . \$20,000

- Install pump . . . . . . . . . . . . . . . . . . . . . . . $\$ 23,000$

TOTAL INITIAL CAPITAL COST $\ldots \ldots \ldots \ldots \ldots \ldots \ldots \ldots \ldots \ldots \ldots \ldots \ldots \ldots \ldots$

Annual Maintenance Cost

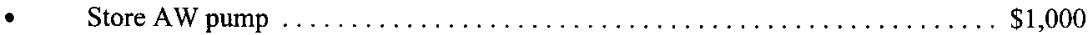

D\&D

- $\quad$ Remove and dispose of one contaminated pump . . . . . . . . . . \$ $\$ 400,000$

\section{Alternative 2: Periodic Pump Removal and Run-in}

Initial Cost

- Fab and run-in AW Farm annulus pump $\ldots \ldots \ldots \ldots \ldots \ldots \ldots \ldots \ldots \ldots \ldots \ldots$

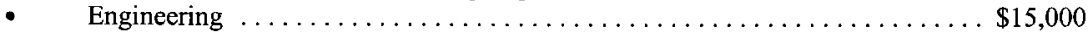

- Install pump in AW annulus

- Work plan . .............................. $\$ 3,000$

- Crane, remove/replace cover block . . . . . . . . . . . . . . . . . . \$15,000

- Install pump . . . . . . . . . . . . . . . . . . . . . . . . . . . . \$ \$23,000

- Establish run-in facility (includes engineering) . . . . . . . . . . . . . . . \$200,000

- Emergency Pumping Installation

- Work plan . . ............................ \$3,000

- Crane, remove/replace cover block on two pits . . . . . . . . . . . . . $\$ 20,000$

- Install pump . . . . . . . . . . . . . . . . . . . . . . \$23,000

TOTAL INITIAL COST $\ldots \ldots \ldots \ldots \ldots \ldots \ldots \ldots \ldots \ldots \ldots \ldots \ldots \ldots \ldots \ldots \ldots \ldots \ldots \ldots$

Annual Maintenance Cost (performed every five years)

- $\quad$ Work plan ................ \$3,000/5 x $6 \ldots \ldots \ldots \ldots \ldots \ldots$

- Crane, remove \& replace cover block . . \$15,000/5 x $6 \ldots \ldots \ldots \ldots \ldots \$ 18,000$

- Remove/replace pump ........... \$23,000/5 x $6 \ldots \ldots \ldots \ldots \ldots \ldots \$ 27,600$

- Maintenance (run-in, bearings) $\ldots \ldots \ldots \ldots 10,000 / 5 \times 6 \ldots \ldots \ldots \ldots \ldots 12,000$

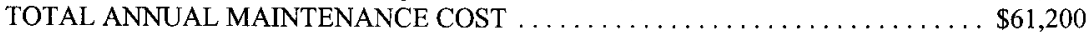

D\&D

- $\quad$ Remove and dispose of one contaminated pump . . . . . . . . . . . \$400,000 


\section{Alternative 3: Periodic In-Place Maintenance}

Initial Cost

- $\quad$ Fab and run-in AW Farm annulus pump $\ldots \ldots \ldots \ldots \ldots \ldots \ldots \ldots \ldots \ldots, \ldots 60,000$

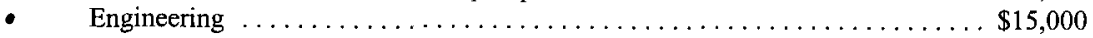

- Emergency Pumping Installation

- Work plan .................................... \$3,000

- Crane, remove/replacc cover block on two pits . . . . . . . . . . . . . \$20,000

- Install pump . . . . . . . . . . . . . . . . . . . . . . . . . . $\$ 23,000$

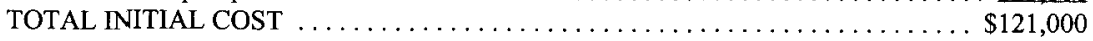

Annual Maintenance Cost (performed every five years)

- $\quad$ Work plan .................... $\$ 3,000 / 5 \times 5 \ldots \ldots \ldots \ldots \ldots 3,000$

- $\quad$ Crane, remove \& replace cover block $\ldots \ldots \$ 10,000 / 5 \times 5 \quad \ldots \ldots \ldots \ldots \ldots \$ 10,000$

- $\quad$ Remove/replace motor ............. \$5,000/5 x $6 \ldots \ldots \ldots \ldots \ldots . \$ 6,000$

- $\quad$ Repack/replace bearings $\ldots \ldots \ldots \ldots \ldots \$ 1,000 / 5 \times 6 \ldots \ldots \ldots \ldots \ldots 1,200$

- Store AW pump .................................. $\$ 1,000$

TOTAL ANNUAL MAINTENANCE COST $\ldots \ldots \ldots \ldots \ldots \ldots \ldots \ldots \ldots \ldots \ldots \ldots \ldots \ldots \ldots \ldots$

D\&D

- Remove and dispose of one contaminated pump ................ $\$ 400,000$

\section{Alternative 4:-Uninstalled Ready Spares (submersible)}

Initial Cost

- $\quad$ Existing Pump Removal

- Work Plan ................ \$3,000 x 5 ............. \$15,000

- Crane, remove \& replace cover block ...\$10,000 x $5 \ldots \ldots \ldots \ldots \ldots . \$ 50,000$

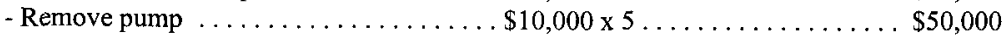

- $\quad$ Procure, fab, and run-in pumps $\ldots \ldots \ldots \ldots \$ 6,000 \times 4 \ldots \ldots \ldots \ldots \ldots \ldots 24,000$

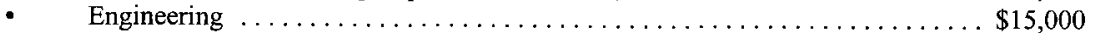

- Electrical Modifications $(\$ 1000$ per DST) $\ldots \ldots \ldots \ldots \ldots \ldots \ldots \ldots \ldots \$ \ldots 28,000$

- Emergency Pumping Installation

- Work plan .................................... \$3,000

- Crane, remove/replace cover block on one pit $\ldots \ldots \ldots \ldots \ldots \ldots \ldots \ldots \ldots 15,000$

- Install pump . . . . . . . . . . . . . . . . . . . . . . . . . . . \$ $\$ 12,000$

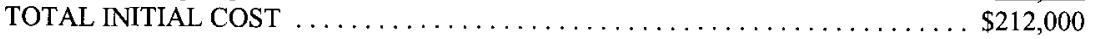

Annual Maintenance Cost

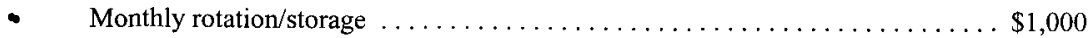

- Five year run-in ................ \$2,500/5 x $4 \ldots \ldots \ldots \ldots \ldots \$ 2,000$

TOTAL ANNUAL MAINTENANCE COST $\ldots \ldots \ldots \ldots \ldots \ldots \ldots \ldots \ldots \ldots \ldots \ldots \$ \ldots 3,000$ 
$\mathrm{D} \& \mathrm{D}$

- Remove and dispose of one contaminated pump . . . . . . . . . . . . \$40,000

\section{Alternative 5: Expanded Mission of SST Emergency Pumping Trailer}

Initial Cost

- Existing Pump Removal

- Work Plan . . . . . . . . . . . \$3,000 x $5 \ldots \ldots \ldots \ldots \ldots \ldots 15,000$

- Crane, remove \& replace cover block . . \$10,000 x $\ldots \ldots \ldots \ldots \ldots \ldots . \$ \ldots 0,000$

- Remove pump .............\$10,000 x $5 \ldots \ldots \ldots \ldots \ldots \ldots \$ \ldots 50,000$

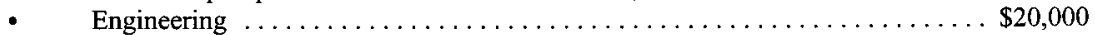

- Procure, fab, and run-in 2 submersible pumps $\ldots \ldots \ldots \ldots \ldots \ldots \ldots \ldots \ldots 12,000$

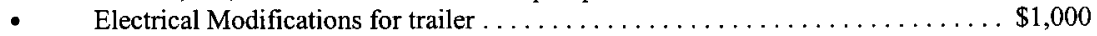

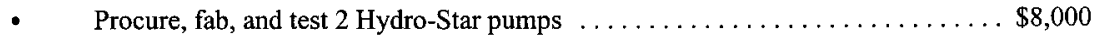

- Emergency Pumping Installation

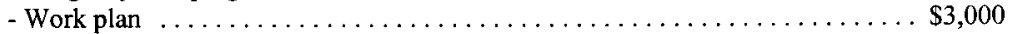

- Crane, remove/replace cover block on one pit $\ldots \ldots \ldots \ldots \ldots \ldots \ldots \ldots \ldots \ldots \ldots \ldots$

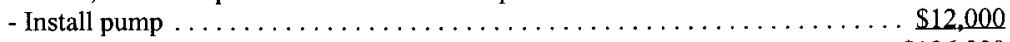

TOTAL INITIAL COST $\ldots \ldots \ldots \ldots \ldots \ldots \ldots \ldots \ldots \ldots \ldots \ldots \ldots \ldots \ldots \ldots \ldots \ldots \ldots$

Annual Maintenance Cost

- Monthly rotation/storage $\ldots \ldots \ldots \ldots \ldots \ldots \ldots \ldots \ldots \ldots \ldots \ldots \ldots \ldots \ldots \ldots$

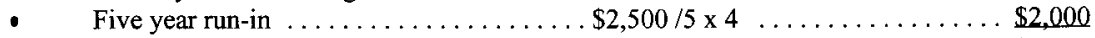

TOTAL ANNUAL MAINTENANCE COST $\ldots \ldots \ldots \ldots \ldots \ldots \ldots \ldots \ldots \ldots \ldots \ldots \ldots$

D\&D

- Remove and dispose of one contaminated pump 
Double-Shell Tank AnNulus Pumping Alternative

Report No. 9905303-001, Rev. 0

\section{Appendix C}

Alternative Life-Cycle Cost Information 


\section{BLCC Summary for Project: Annulus Pump Maintenance Alternative: Continue Status Quo (with disposal)}

Filename: NOTHING.DAT

Date of Analysis: 02-11-1999/15:08:42

Analysis Type: Federal Analysis--Projects Subject to OMB A-94

Study Period: $\quad 21.00$ Years (FEB 1999 through JAN 2020)

Plan/Constr. Period: 0.92 Years (FEB 1999 through DEC 1999)

Service Period: $\quad 20.08$ Years (JAN 2000 through JAN 2020)

Discount Rate: $3.71 \%$

Initial Cost (as of Service Date) Annually Recurring OM\&R Costs Non-An. Recurring OM\&R Costs Less: Remaining Value
Present Value

$\$ 44,489$

$\$ 13,775$

$\$ 322,445$

-0 .
Annual Value

$\$ 3,087$

$\$ 956$

$\$ 22,374$

-0 -

Total LCC

$\$ 380,709$

$\$ 26,417$

\section{BLCC Summary for Project: Annulus Pump Maintenance Alternative: Continue Status Quo (without disposal)}

Filename: NOTHING1.DAT Date of Analysis: 02-11-1999/15:13:27

Analysis Type: Federal Analysis--Projects Subject to OMB A-94

Study Period: $\quad 21.00$ Years (FEB 1999 through JAN 2020)

Plan/Constr. Period: 0.92 Years (FEB 1999 through DEC 1999)

Service Period: $\quad 20.08$ Years (JAN 2000 through JAN 2020)

Discount Rate: $3.71 \%$

Initial Cost (as of Service Date)

Annually Recurring OM\&R Costs

Less: Remaining Value

\section{Present Value}

$\$ 44,489$

$\$ 13,775$

$-0-$
Annual Value

$\$ 3,087$

$\$ 956$ -0 -

Total LCC

$\$ 58,264$

$\$ 4,043$ 


\section{BLCC Summary for Project: Annulus Pump Maintenance} Alternative: Run-in (with disposal)

Filename: RUNIN.DAT

Date of Analysis: 02-11-1999/15:09:56

Analysis Type: Federal Analysis--Projects Subject to OMB A-94

Study Period:

21.00 Years (FEB 1999 through JAN 2020)

Plan/Constr. Period: 0.92 Years (FEB 1999 through DEC 1999)

Service Period: $\quad 20.08$ Years (JAN 2000 through JAN 2020)

Discount Rate: $3.71 \%$

Initial Cost (as of Service Date)

Annually Recurring OM\&R Costs

Non-An. Recurring OM\&R Costs

Less: Remaining Value

$\begin{array}{rr}\text { Present Value } & \text { Annual Value } \\ \$ 325,933 & \$ 22,616 \\ \$ 843,019 & \$ 58,497 \\ \$ 224,001 & \$ 15,543 \\ -0- & -0-\end{array}$

$\$ 1,392,953$

$\$ 96,656$

Total LCC

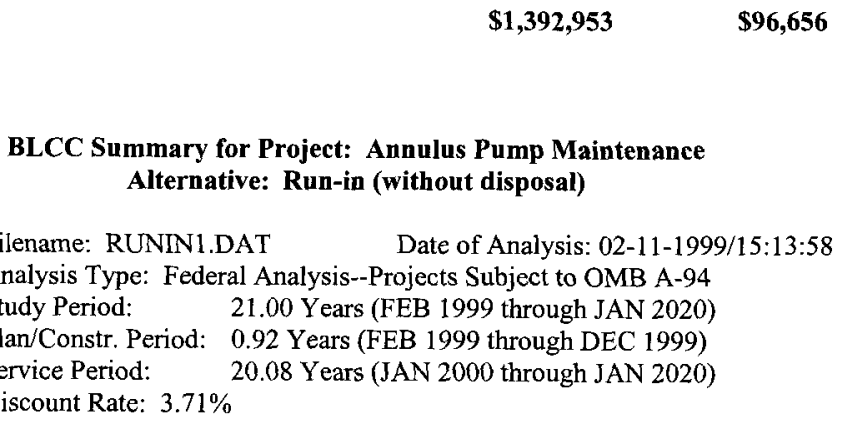

Discount Rate: $3.71 \%$

Initial Cost (as of Service Date)

Annually Recurring OM\&R Costs

Less: Remaining Value
Present Value

$\$ 325,933$

$\$ 843,019$

-0 -
Annual Value

$\$ 22,616$

$\$ 58,497$

-0 -

Total LCC

$\$ 1,168,952$

$\$ 81,113$ 


\section{BLCC Summary for Project: Annulus Pump Maintenance Alternative: In-Place (with disposal)}

Filename: INPLACE.DAT

Date of Analysis: 02-11-1999/15:10:59

Analysis Type: Federal Analysis--Projects Subject to OMB A-94

Study Period:

21.00 Years (FEB 1999 through JAN 2020)

Plan/Constr. Period:

Service Period:

Discount Rate: $3.71 \%$

0.92 Years (FEB 1999 through DEC 1999)

20.08 Years (JAN 2000 through JAN 2020)

Initial Cost (as of Service Date) Annually Recurring OM\&R Costs Non-An. Recurring OM\&R Costs Less: Remaining Value

Present Value
$\$ 117,026$
$\$ 292,026$
$\$ 268,752$
$-0-$

Annual Value

$\$ 8,120$

$\$ 20,264$

$\$ 18,649$

-0 -

Total LCC

$\$ 677,805$

$\$ 47,032$

BLCC Summary for Project: Annulus Pump Maintenance Alternative: In-Place (without disposal)

Filename: INPLACE1.DAT

Date of Analysis: 02-11-1999/15:14:31

Analysis Type: Federal Analysis--Projects Subject to OMB A-94

Study Period: 21.00 Years (FEB 1999 through JAN 2020)

Plan/Constr. Period: 0.92 Years (FEB 1999 through DEC 1999)

Service Period: $\quad 20.08$ Years (JAN 2000 through JAN 2020)

Discount Rate: $3.71 \%$

Initial Cost (as of Service Date)

Annually Recurring OM\&R Costs

Less: Remaining Value
Present Value

$\$ 117,026$

$\$ 292,026$

-0 -
Annual Value

$\$ 8,120$

$\$ 20,264$

-0-

Total LCC

$\$ 409,053$

$\$ 28,384$ 


\section{BLCC Summary for Project: Annulus Pump Maintenance Alternative: Ready Spares (with disposal)}

Filename: READY.DAT

Date of Analysis: 02-11-1999/15:19:15

Analysis Type: Federal Analysis--Projects Subject to OMB A-94

Study Period:

21.00 Years (FEB 1999 through JAN 2020)

Plan/Constr. Period: 0.92 Years (FEB 1999 through DEC 1999)

Service Period: $\quad 20.08$ Years (JAN 2000 through JAN 2020)

Discount Rate: $3.71 \%$

Initial Cost (as of Service Date)

Annually Recurring OM\&R Costs

Non-An. Recurring OM\&R Costs

Less: Remaining Value

Present Value
$\$ 205,038$
$\$ 41,324$
$\$ 22,400$
$-0-$

$\$ 268,762$
Annual Value

$\$ 14,227$

$\$ 2,867$

$\$ 1,554$ -0 -

Total LCC

\$268,762
BLCC Summary for Project: Annulus Pump Maintenance
Alternative: Ready Spares (without disposal)
Datename: READY1.DAT $\quad$ Date Analysis: 02-11-1999/
Analysis Type: Federal Analysis--Projects Subject to OMB A-94
21.00 Years (FEB 1999 through JAN 2020)
lan/Constr. Period: 0.92 Years (FEB 1999 through DEC 1999)
20.08 Years (JAN 2000 through JAN 2020)
Discount Rate: $3.71 \%$

$\$ 18,649$

Initial Cost (as of Service Date)

Annually Recurring OM\&R Costs

Less: Remaining Value
Present Value
$\$ 205,038$
$\$ 41,324$
-0 -




\section{BLCC Summary for Project: Annulus Pump Maintenance Alternative: Trailer (with disposal)}

Filename: TRAILER.DAT

Date of Analysis: 02-11-1999/15:12:30

Analysis Type: Federal Analysis--Projects Subject to OMB A-94

Study Period: $\quad 21.00$ Years (FEB 1999 through JAN 2020)

Plan/Constr. Period: 0.92 Years (FEB 1999 through DEC 1999)

Service Period: $\quad 20.08$ Years (JAN 2000 through JAN 2020)

Discount Rate: $3.71 \%$

Initial Cost (as of Service Date) Annually Recurring OM\&R Costs Non-An. Recurring OM\&R Costs

Less: Remaining Value

\section{Present Value}

$\$ 179,892$

$\$ 41,324$

$\$ 22,400$

-0 -
Annual Value

$\$ 12,483$

$\$ 2,867$

$\$ 1,554$

$-0-$

Total LCC

$\$ 243,616$

$\$ 16,904$

\section{BLCC Summary for Project: Annulus Pump Maintenance Alternative: Trailer (without disposal)}

Filename: TRAILER1.DAT

Date of Analysis: 02-11-1999/15:20:36

Analysis Type: Federal Analysis--Projects Subject to OMB A-94

Study Period: $\quad 21.00$ Years (FEB 1999 through JAN 2020)

Plan/Constr. Period: 0.92 Years (FEB 1999 through DEC 1999)

Service Period: $\quad 20.08$ Years (JAN 2000 through JAN 2020)

Discount Rate: $3.71 \%$

Initial Cost (as of Service Date)

Annually Recurring OM\&R Costs

Less: Remaining Value
Present Value
$\$ 179,892$
$\$ 41,324$
$-0-$

Annual Value

$\$ 12,483$

$\$ 2,867$

$-0-$

Total LCC

$\$ 221,216$

$\$ 15,350$ 

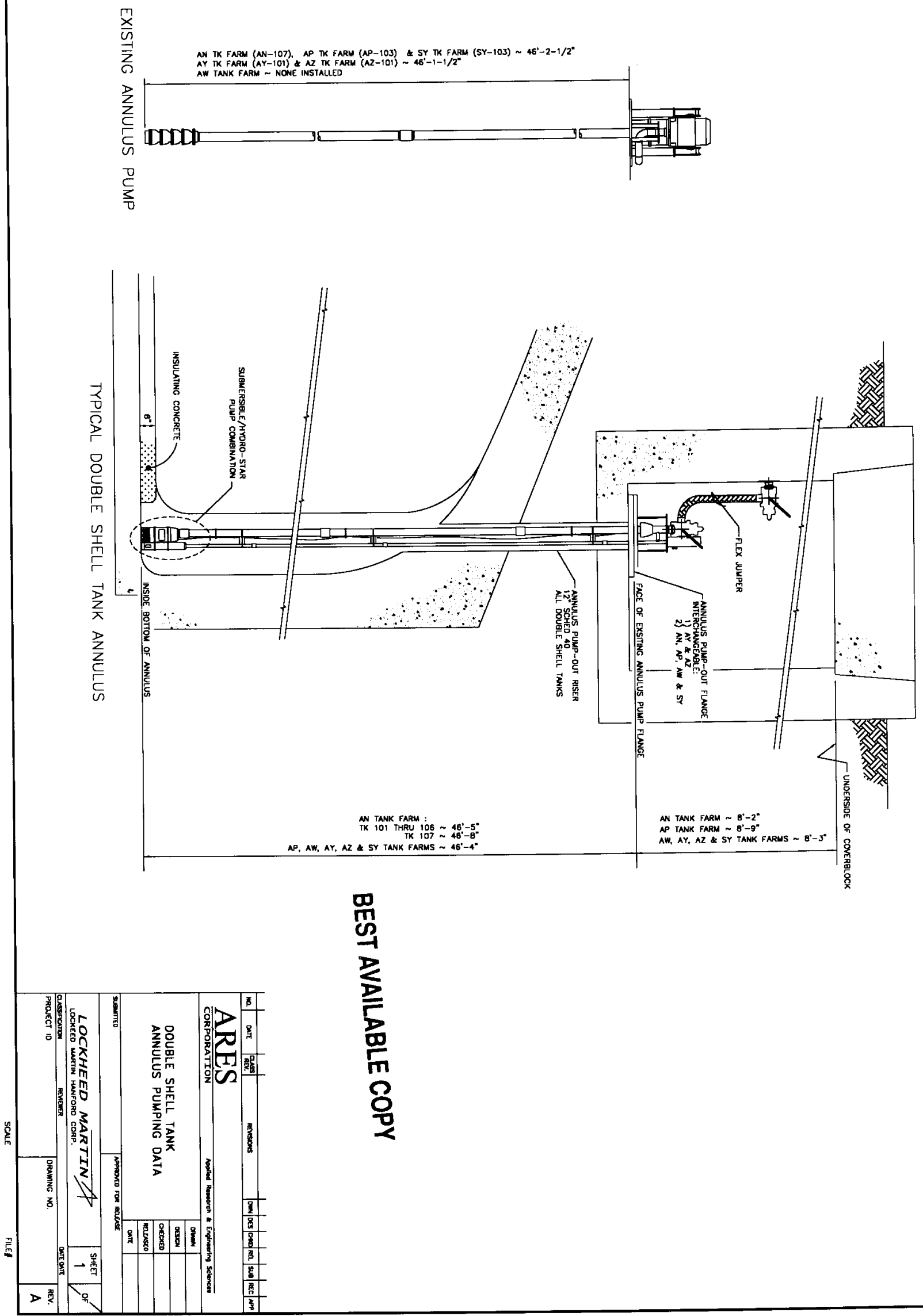


\section{DISTRIBUTION SHEET}

\begin{tabular}{|c|c|c|c|c|c|}
\hline \multirow{2}{*}{$\begin{array}{l}\text { To } \\
\text { Distribution }\end{array}$} & \multirow{2}{*}{\multicolumn{3}{|c|}{$\begin{array}{l}\text { From } \\
\text { RW Reed }\end{array}$}} & \multicolumn{2}{|l|}{ Page 1 of 1} \\
\hline & & & & \multicolumn{2}{|c|}{ Date 31 March 1999} \\
\hline \multirow{2}{*}{\multicolumn{4}{|c|}{$\begin{array}{l}\text { Project Title/Work Order } \\
\text { HNF-4241 Rev.0, Double-Shell Tank Annulus Pumping Alternative } \\
\text { Evaluation }\end{array}$}} & \multicolumn{2}{|c|}{ EDT No. 616409} \\
\hline & & & & \multicolumn{2}{|c|}{ ECN No. N/A } \\
\hline \multicolumn{2}{|l|}{ Name } & $\begin{array}{l}\text { Text } \\
\text { With All } \\
\text { Attach. }\end{array}$ & Text Only & $\begin{array}{l}\text { Attach./ } \\
\text { Appendix } \\
\text { Only }\end{array}$ & $\begin{array}{r}\text { EDT/EC } \\
\text { N Only }\end{array}$ \\
\hline \multicolumn{2}{|l|}{ DG Baide } & $x$ & & & \\
\hline \multirow{2}{*}{$\begin{array}{l}\text { MH Brown } \\
\text { BG Erlandson (3) }\end{array}$} & T4-07 & $x$ & & & \\
\hline & R1-51 & $x$ & & & \\
\hline $\begin{array}{l}\text { BG Erlandson (3) } \\
\text { HR Hopkins }\end{array}$ & $R 2-58$ & $x$ & & & \\
\hline $\begin{array}{l}\text { JW Hunt } \\
\text { RE Larson }\end{array}$ & $\mathrm{R} 2-12$ & $x$ & & & \\
\hline RE Larson & T4-07 & $x$ & & & \\
\hline PC Miller & R1-51 & $x$ & & & \\
\hline MA Payne & $R 2-58$ & $x$ & & & \\
\hline & $\mathrm{R} 2-58$ & $x$ & & & \\
\hline RE Raymond & R2-38 & $x$ & & & \\
\hline DW Reberger (6) & S5-13 & $x$ & & & \\
\hline RW Reed & T4-07 & $x$ & & & \\
\hline RJ Shupe & $R 2-50$ & $x$ & & & \\
\hline DB Smet & R1-56 & $x$ & & & \\
\hline RP Tucker & T4-07 & $x$ & & & \\
\hline MJ Sutey & S5-07 & $x$ & & & \\
\hline
\end{tabular}

